\title{
Clinical characteristics of adult uncorrected secundum atrial septal defect: a pilot study
}

\author{
Lucia Krisdinarti ${ }^{1}$, Anggoro Budi Hartopo ${ }^{1 *}$, Dyah Wulan Anggrahini ${ }^{1}$, Ahmad Hamim \\ Sadewa ${ }^{2}$, Abdus Samik Wahab ${ }^{1,3}$, Budi Yuli Setianto ${ }^{1}$, \\ ${ }^{1}$ Department of Cardiology and Vascular Medicine, Faculty of Medicine/Dr. Sardjito Gen- \\ eral Hospital, '2Department of Biochemistry, Faculty of Medicine, ${ }^{3}$ Department of Child \\ Health, Faculty of Medicine/Dr. Sardjito General Hospital, Universitas Gadjah Mada, \\ Yogyakarta, Indonesia
}

DOI: http://dx.doi.org/10.19106/JMedSci004802201603

\begin{abstract}
Atrial septal defect (ASD) is the most frequent congenital heart disease in adulthood. Pulmonary hypertension (PH) complicating ASD compels patients seeking medical assistance because of its disabling symptom. Most adult ASD develop PH which render significant morbidity and mortality. The aim of the study is to characterize the clinical profiles of adult patients with ASD. The study design was cross sectional. The subjects were enrolled consecutively from outpatient clinics and inpatient wards. The demography, medical and imaging data were collected and recorded in case report form. Descriptive statistics was applied to characterize the subjects. Seventy-six subjects were enrolled. The majority were women $(77.6 \%)$ in the productive and child-bearing ages $(63.2 \%)$. The most common symptoms were dyspneu on effort, fatigue, and palpitation. Most subjects had functional capacity of WHO class functional II (70.2 \%). The mean oxygen saturation was $96.4 \%$. Based on the echocardiography examination, $77.6 \%$ of subjects had suffered from PH. The mean longest diameter of defects were $2.7 \mathrm{~cm}$. The direction of blood flow was mostly left to right $(77.6 \%)$. Left and right ventricle function were within normal limit. Right heart catheterization showed mean left atrial pressure 11.5 $\mathrm{mmHg}$, which confirmed the precapillary or arterial $\mathrm{PH}$. Mean pulmonary artery pressure was $42.0 \mathrm{mmHg}$. The pulmonary artery resistance index mostly less than 4 Wood Unit/ $\mathrm{m}^{2}(63.7 \%)$, indicating the feasibility to close the defect. Whereas $24.6 \%$ of subjects were contraindicated for closing. Pulmonary artery hypertension (PAH) was diagnosed in $77.6 \%$ subjects, meanwhile $13.2 \%$ had borderline PAH. In conclusion, most adult ASD patients had developed $\mathrm{PAH}$, mostly young women in productive ages, mainly visited hospital due to symptom of $\mathrm{PH}$, the direction of flow predominantly left to right side and mostly had reduced functional capacity.
\end{abstract}

\section{ABSTRAK}

Defek septum atrium (DSA) merupakan penyakit jantung bawaan yang paling sering dijumpai pada usia dewasa karena tanda dan gejalanya yang samar. Hipertensi paru (HP) merupakan komplikasi DSA yang mendorong pasien ke rumah sakit karena munculnya gejala yang berat. Hampir semua pasien DSA dewasa mengalami HP yang menyebabkan angka kesakitan dan kematian bermakna. Tujuan penelitian ini adalah untuk mengkaji karakteristik klinis pasien dengan DSA dan HP. Desain penelitian adalah potong lintang.

Corresponding author: a_bhartopo@ugm.ac.id 
Subjek diseleksi secara berurutan dari klinik rawat jalan dan rawat inap. Data demografi, medis dan pencitraan dikumpulkan dan dicatat dalam suatu blangko laporan kasus. Penelitian deskriptif dilakukan untuk menilai karakteristik subjek. Sebanyak tujuh puluh enam subjek dilibatkan dalam penelitian. Sebagian besar subjek adalah wanita $(77,6 \%)$ usia muda, produktif dan subur $(63,2 \%)$. Gejala paling sering adalah sesak saat aktivitas, mudah lelah, dan berdebar. Sebagian besar pasien masuk dalam kelas fungsional WHO II $(70,2 \%)$. Rerata saturasi oksigen $96,4 \%$. Berdasar hasil ekokardiografi, sebanyak $77,6 \%$ subjek telah mengalami HP. Rerata diameter terpanjang defek adalah $2,7 \mathrm{~cm}$. Arah aliran darah melewati defek sebagian besar kiri ke kanan $(77,6 \%)$. Fungsi ventrikel kanan dan kiri dalam batas normal. Kateterisasi jantung kanan menunjukkan rerata tekanan atrium kiri sebesar $11,5 \mathrm{mmHg}$ yang menandakan HP prekapiler/arteri. Rerata tekanan arteri pulmonalis sebesar $42,0 \mathrm{mmHg}$. Nilai indeks tahanan arteri pulmonalis sebagian besar kurang dari 4 Wood unit $/ \mathrm{m}^{2}(63,7 \%)$ yang menunjukkan kemungkinan bisa dilakukan penutupan defek. Sedangkan $24,6 \%$ subjek kontraindikasi untuk penutupan. Hipertensi arteri pulmonalis (HAP) didiagnosis pada $77,6 \%$ subjek, sedangkan $13,2 \%$ subjek mengalami HAP borderline. Sebagai kesimpulan, sebagian besar DSA dewasa telah mengalami HAP, sebagian besar wanita muda yang berusia produktif, sebagian besar mengunjungi rumah sakit karena gejala HP, arah aliran sebagian besar dari kiri ke kanan dan sebagian besar telah mengalami penurunan kapasitas fungsional.

Keywords: atrial septal defect - pulmonal hypertension - pulmonary artery hypertension echocardiography - symptoms

\section{INTRODUCTION}

Atrial septal defect (ASD) is a congenital heart defect marked by an opening in the interatrial septum. The gap triggers the blood flowing from left atrium to right atrium initially. Atrial septal defect is one of the most common acyanotic congenital heart diseases. Its clinical manifestation often so indistinct that it is frequently missed during chilhood. Undiagnosed ASD, therefore uncorrected, may progress to develop pulmonary hypertension $(\mathrm{PH})$. The disabling symptom of PH compels patients to seek medical help, usually in young adult period. Hence, ASD is the most common congenital heart disease encountered in adulthood. ${ }^{1}$

On the whole, the prevalence of congenital heart defect is estimated to be 81.4 infants per 10,000 births ( $0.8 \%$ of live births). ${ }^{2}$ Among them, ASD constitutes $6 \%$ of all congenital heart diseases, with woman mostly affected by the ratio of $2: 1$ as compare to man. ${ }^{3}$ The prevalence of secundum ASD is approximated to be 10.3 per 10,000 live births. ${ }^{2}$ Based on location of the opening, ASD can be divided into three cathegories, i.e. primum, secundum and sinus venosus ASD. Secundum ASD is the most common type, which accounts for greater than $80 \%$ of all ASD. ${ }^{2}$

The force and direction of blood flow across the opening of ASD depend on pressure and hemodynamic of right and left ventricles. Right ventricle compliance and low pressure creates left to right blood flow which subsequently overflowing into pulmonary vasculatures. Overtime, it produces increased pulmonary vascular resistance and subsequent $\mathrm{PH}$ and reduces right ventricle compliance. The reversal of flow, from right to left side, succeedingly occurs and worsens patients clinical condition. ${ }^{4}$ Patients with ASD and $\mathrm{PH}$ have significant morbidity and mortality if untreated. Current guideline emphasize medication for alleviating $\mathrm{PH}$ in unoperable 
ASD, while correction for the defect remain controversial. ${ }^{5}$ Currently no available local and national data in adult ASD have been published. Conforming the guideline for treatment of PH due to untreated congenital heart disease, ${ }^{5}$ it is necessary to characterize the adult patients with ASD and $\mathrm{PH}$ in order to better understand the pathophysiology of the disease and guide suitable treatment. The aim of the study is to characterize the clinical data of adult patients with ASD and PH.

\section{MATERIALS AND METHODS}

\section{Subject}

The research design was a cross sectional. The subjects of the research were adult patients with ASD whom visited outpatient clinics or admitted to inpatient wards of Dr. Sardjito General Hospital, Yogyakarta, Indonesia. The time of enrollment was June 2012 until December 2013. The subjects were enrolled consecutively and given informed consent to participate in the research. The inclusion criteria was (1) patients with unoperated or unclosed secundum ASD, (2) patients $>18$ years of age and (3) patients have been performed transthoracal echocardiography and right heart catheterization. The exclusion criteria was (1) patients with other congenital heart defect and (2) pregnant patients.

\section{Protocol of the study}

Demography data was collected and recorded. The WHO functional class was determined based on WHO classification on functional daily activity limitation due to $\mathrm{PH}$, ranging from $\mathrm{I}-\mathrm{IV} .^{5}$ The 6 minute walk test was performed by walking as convenient as possible in level surface within 6 minutes, the distance of walking was measured and recorded. The oxygen saturation was detected by fingertip pulse oxymetri. Laboratory data was obtained from hospital laboratory. Transthoracal echocardiography was performed by a sonographer and interpreted by a cardiologist consultant. Pulmonary hypertension based on echocardiography was determined by estimating pulmonary artery systolic pressure (PASP) using standard formula. The PASP $\geq 40 \mathrm{mmHg}$ was determined as $\mathrm{PH}$. The right heart catheterization was performed and interpreted by a cardiologist consultant. At the time of study, Swan-Ganz catheter to measure pulmonary capillary wedge pressure was not available in our hospital, therefore left atrial pressure was determined as a surrogate. Pulmonary artery hypertension $(\mathrm{PAH})$ was determined as value of mean pulmonary artery pressure (mPAP) $\geq 25 \mathrm{mmHg}$ and left atrial pressure (LAP) $\leq 15 \mathrm{mmHg}$. Other parameters were obtained from standard formulas. All intervention was part of standard care of the patients and was not influenced by this research. The protocol of study had been approved by Medical and Health Research Ethics Committee, Faculty of Medicine Universitas Gadjah Mada.

\section{Data analysis}

The descriptive statistics was employed. Since the research did not aim to test the hypothesis, specific statistics analysis was not applied.

\section{RESULTS}

We enrolled 76 subjects to be included in the study based on research criteria. All of the subjects had secundum ASD. The majority of the subjects were women (77.6\%) and were in young, productive and childbearing ages [i.e. 18-40 years of age (63.2 $\%)]$. The most common symptoms urging the subjects to seek medical help were dyspneu on effort (47.4\%), easily fatigue (15.8\%), 
and palpitation (13.2\%). Most patients were underweight $(47.8 \%)$ as indicated by body mass index $(\mathrm{BMI})<18.5$. TABLE 1 showed the demographic characteristics of subjects with secundum ASD.

TABLE 1. Demographic characteristics of secundum ASD patients

\begin{tabular}{lc}
\hline Characteristics & Frequency \\
\hline Age [(years), $\mathrm{n}(\%)]$ & $76(100)$ \\
- $18-30$ & $32(42.1)$ \\
- $31-40$ & $16(21.1)$ \\
- $41-50$ & $17(22.4)$ \\
- $51-60$ & $7(9.2)$ \\
- > 60 & $4(5.3)$ \\
Gender, n (\%) & $76(100)$ \\
- Men & $17(22.4)$ \\
- Women & $59(77.6)$ \\
Body mass index [n (\%)] & $69(100)$ \\
Underweight & $33(47.8)$ \\
Normal & $30(43.5)$ \\
Overweight & $6(8.6)$ \\
Symptoms [n (\%)] & $76(100)$ \\
Dispneu on effort & $36(47.4)$ \\
Easily fatique & $12(15.8)$ \\
Palpitation & $10(13.2)$ \\
Chest pain & $8(10.5)$ \\
Cough & $5(6.6)$ \\
Chest dyscomfort & $1(1.3)$ \\
Headache & $1(1.3)$ \\
None & $3(3.9)$ \\
\hline
\end{tabular}

Based on WHO functional class, most subjects were classified in class functional II $(71.2 \%)$, whereas only $8.1 \%$ subjects were in WHO class functional I. About 20\% subjects had disabling symptoms (WHO class functional III-IV). Functional capacity of the subjects, measured with 6 minute walk test, was reduced. The mean walking distance was $336.0 \mathrm{~m}$, while normal subjects can reach more than $700 \mathrm{~m}$. The oxygen saturation detected by pulse oxymetri showed mean saturation of $96.4 \%$, which was within normal acceptable value. Mean haemoglobin value was 13.1 $\mathrm{g} / \mathrm{dL}$ which was considered normal level. TABLE 2 showed the clinical and laboratory characteristics of subject with secundum ASD.

TABLE 2. Clinical and laboratory characteristics of secundum ASD patients

\begin{tabular}{lc}
\hline Characteristics & Frequency \\
\hline WHO functional class [n (\%)] & $76(100)$ \\
- I & $6(7.8)$ \\
- II & $54(71.2)$ \\
- III & $15(19.7)$ \\
- IV & $1(1.3)$ \\
Blood pressure [mean \pm SD & \\
(mmHg)] & \\
- Systolic & $119.8 \pm 21.7$ \\
- Diastolic & $75.9 \pm 11.7$ \\
Oxygen saturation [mean $\pm \mathrm{SD}$ & $96.4 \pm 4.7$ \\
$(\%)]$ & \\
6 minute walk test [mean $\pm \mathrm{SD}$ & $336.0 \pm 144.6$ \\
(m)] & \\
Laboratory [mean $\pm \mathrm{SD}]$ & \\
Haemoglobin $(\mathrm{g} / \mathrm{dL})$ & $13.1 \pm 2.0$ \\
Hematocrit $(\%)$ & $40.2 \pm 5.5$ \\
\hline
\end{tabular}

The echocardiography is an important tool to diagnose ASD and estimate pulmonary artery pressure. Based on the transthoracal echocardiography examination, $77.6 \%$ of subjects had suffered from $\mathrm{PH}$, indicated by PASP $>40 \mathrm{mmHg}$. Measurement of defects in interatrial septum revealed the mean longest diameter of ASD were $2.7 \mathrm{~cm}$. Most subjects had right atrium and right ventricle chamber enlargement, with mean diameters of 45.5 $\mathrm{mm}$ and $44.8 \mathrm{~mm}$, respectively. Left atrium and left ventricles dimension were within normal value. Left ventricle ejection fraction was normal, right ventricle function was normal as well. The direction of blood flow 
across the shunt was mostly left to right side, i.e. 59 subjects $(77.6 \%)$, whereas bidirectional shunt was observed in 17 subjects $(22.4 \%)$. Severe tricuspid regurgitation occurred in 23 subjects $(30.3 \%)$, moderate regurgitation in
37 subjects $(48.7 \%)$ and mild regurgitation in 16 subjects $(21.1 \%)$. Pericardial effusion was detected in 4 subjects (5.3\%). TABLE 3 depicted the transthoracal echocardiographic parameters of subjects with secundum ASD.

TABLE 3. Echocardiographic findings in ASD patients

\begin{tabular}{lc}
\hline Parameters & Frequency \\
\hline Pulmonary hypertension $[\mathrm{n}(\%)]$ & $59(77.6)$ \\
Longest defect size $[$ mean $\pm \mathrm{SD}(\mathrm{cm})]$ & $2.7 \pm 0.7$ \\
Right atrium diameter $[\mathrm{mean} \pm \mathrm{SD}(\mathrm{mm})]$ & $45.5 \pm 7.4$ \\
Right ventricle diameter $[\mathrm{mean} \pm \mathrm{SD}(\mathrm{mm})]$ & $44.8 \pm 6.8$ \\
Tricuspid TVG [mean $\pm \mathrm{SD}(\mathrm{mmHg})]$ & $62.0 \pm 32.4$ \\
Pulmonary artery SP $[\mathrm{mean} \pm \mathrm{SD}(\mathrm{mmHg})]$ & $58.3 \pm 21.9$ \\
TAPSE [mean $\pm \mathrm{SD}(\mathrm{mmHg})]$ & $25.4 \pm 5.9$ \\
Left ventricle ejection fraction $[\mathrm{mean} \pm \mathrm{SD}(\%)]$ & $70.7 \pm 9.5$ \\
Flow direction [n $(\%)]$ & $76(100)$ \\
- Left to right & $59(77.6)$ \\
- Bidirectional & $17(22.4)$ \\
Tricuspid regurgitation $[\mathrm{n}(\%)]$ & $76(100)$ \\
- Mild & $16(21.1)$ \\
- Moderate & $37(48.7)$ \\
- Severe & $23(30.3)$ \\
Pericard effusion, n $(\%)$ & $4(5.3)$ \\
\hline TAPSE, Tricuspid Annular Plane Systolic & Excursion; $\mathrm{TVG}$, \\
transvalvular gradient, SP, systolic pressure &
\end{tabular}

Right heart catheterization is an important diagnostic tool to visualize ASD and a gold standard to assess the presence of PAH. It is a crucial step to evaluate the indication of ASD closure, since hemodynamic data can be obtained. Mean left atrial pressure (LAP) was $11.5 \mathrm{mmHg}$. It was a surrogate for pulmonary capillary wedge pressure (PCWP), which confirmed the diagnosis of precapillary or arterial $\mathrm{PH}$ in ASD. Mean value of mean pulmonary artery pressure (mPAP) was 42.0 $\mathrm{mmHg}$. Subjects with $\mathrm{mPAP} \geq 25 \mathrm{mmHg}$ and LAP $\leq 15 \mathrm{mmHg}$ were cathegorized as having PAH. Therefore, 59 subjects $(77.6 \%)$ had suffered from $\mathrm{PAH}$, meanwhile 10 subjects (13.2\%) had borderline PAH (mPAP 21 - 25 $\mathrm{mmHg}$ ) and 7 subjects (9.2\%) had no PAH. Based on pulmonary artery resistance index (PARI) value (only calculated in 71 subjects), $63.7 \%$ subjects had PARI $<4$ Wood Unit $/ \mathrm{m}^{2}$, indicating the feasibility to close the ASD. The PARI value $>8$ Wood Unit $/ \mathrm{m}^{2}$, which is a contraindication to close the defect, occurred in $24.6 \%$ subjects. Mean flow ratio was 2.9 and mean Qp/Qs was 1.3, indicating that the majority of subjects had excess pulmonary flow. TABLE 4 showed the right heart catheterization results. 
TABLE 4. Right heart catheterisation results of secundum ASD patients

\begin{tabular}{lc}
\hline Parameters & Frequency \\
\hline Left atrial pressure $[$ mean $\pm \mathrm{SD}(\mathrm{mmHg})]$ & $11.5 \pm 5.3$ \\
Mean PA pressure [mean $\pm \mathrm{SD}(\mathrm{mmHg})]$ & $42.0 \pm 21.8$ \\
Flow ratio [mean $\pm \mathrm{SD}]$ & $2.9 \pm 1.9$ \\
PARI [n (\%) (Wood Unit/m²)] & $71(100)$ \\
- $<4$ & $44(61.9)$ \\
- $4-8$ & $8(11.2)$ \\
- $>8$ & $17(23.9)$ \\
Qp/Qs [mean \pm SD] & $1.3 \pm 0.8$ \\
Systemic oxygen saturation $[\mathrm{mean} \pm \mathrm{SD}(\%)]$ & $91.4 \pm 7.5$ \\
Pulmonary artery hypertension $[\mathrm{n}(\%)]$ & $76(100)$ \\
- Yes & $59(77.6)$ \\
- Borderline & $10(13.2)$ \\
- No & $7(9.2)$ \\
\hline
\end{tabular}

PARI, pulmonary artery resistance index, PA, pulmonary artery

\section{DISCUSSION}

Our research was the first study describing the demography, medical and imaging data of adult patients with uncorrected secundum ASD in Indonesia. Most patients were undiagnosed previously and unaware that they had congenital heart disease. Indeed, among congenital heart diseases, ASD often asymptomatic or only demonstrates mild atypical symptom during childhood. Its acyanotic nature and functionally tolerable, supplemented by no good screening system during childhood, makes ASD the most common congenital heart disease encountered in adult life in developing countries. Current availability of imaging technique and expertise in our centre, i.e. right heart catheterisation, bring about the accurate diagnosis, supportive data for closure the defect and evaluation of treatment. However, most adult ASD with $\mathrm{PH}$ could not be treated curatively by defect closure because of its PAH complication. The closure will be deteriorating for such patients. Therefore, reliance to medication for reducing pulmonary artery pressure is encouraged to improve quality of life. The data of the characteristics of such patients is of paramount important to provide epidemiological profile and burden of disease which affect the local and national health policy.

Our data showed that the majority of patients were young adult women, which account for nearly $80 \%$. Epidemiology study showed that ASD are not uncommon and can present at any phase of age. Women constitute around $65 \%$ until $75 \%$ in patients with secundum ASD. ${ }^{3}$ Since all of our patients were secundum ASD, it confirmed previous epidemiology data. Most of the patients was in child-bearing ages which pose greater risk of morbidity and mortality if they become pregnant. Furthermore, those with $\mathrm{PH}$ will be contraindicated for pregnancy due to increasing mortality rate. Unlike secundum ASD, gender distribution is similar for ostium primum ASD and sinus venosus defect. ${ }^{3}$

Most of the patients had been symptomatic which was related to PH. Dyspneu on effort, 
easily fatique and palpitation were the most common complaints urging patients to visit hospital. Pulmonary hypertension complicating ASD is encountered in 6-35\% of untreated patients in later adulthood. ${ }^{6}$ The presence of $\mathrm{PH}$ causes progressive dyspneu, presyncope, syncope, edema and functional limitations. ${ }^{7}$ Furthermore, right ventricular volume overload and right ventricular dysfunction generate more progressive sign and symptom. ${ }^{6}$ Palpitation is possibly the indication of impending heart failure or arrhytmia. Supraventricular arrhythmia, due to stretching of the conduction system, may be the first presenting sign of an ASD. ${ }^{8}$ In patients with uncorrected ASD, the clinical parameters tend to worsen over time. ${ }^{6}$ Nevertheless, a substantial number of patients with open ASD have normal parameters, usually the patients with small defects in whom the hemodynamic parameters remained stable during several years of follow up. ${ }^{6}$ In our cohorts, despite developing $\mathrm{PH}$, around $6 \%$ of patients come in later life (sixth decade). The long period of asymptomatic or mild symptom may be associated with small ASD. Large ASD (i.e. defect $>2 \mathrm{~cm}$ ) are at risk to develop Eisenmenger syndrome, which prevalence approximately $10 \% .^{9}$ It is still unknown as to whether the $\mathrm{PH}$ does not develop in some patients, while in others it progresses rapidly regardless the defect size.

Based on echocardiogram parameters, most of patients in our study have advanced into $\mathrm{PH}$. The mean longest defect size was $>2 \mathrm{~cm}$, which is a significantly large defect . This may partially explain the pathophysiology of $\mathrm{PH}$ as a natural history of large ASD defects. Right ventricular volume overload has been detected in all patients which contribute to progressing symptom in about $90 \%$ patients with WHO functional class more than II. The right ventricular dysfunction and right heart failure have not yet developed in our study patients, indicated by normal tricuspid annular plane systolic excursion (TAPSE) value. Right ventricular noncompliance occurs in fetal life as a result of high pulmonary vascular resistance allowing the right to left flow at the atrial level. Instantly after delivery, the right ventricular compliance is similar to that of left ventricle, therefore only little shunting flow through the defect. $^{8}$ Overtime, pulmonary vascular resistance decreases physiologically and right ventricular wall becomes thinner, resulting in reduced compliance and left to right blood flow which develop in children and young adult period. ${ }^{8}$

Right heart catheterisation is a tool to confirm PAH. Pulmonary artery hypertension related to ASD is included in group I of $\mathrm{PH}$ clinical classification. ${ }^{5}$ In addition to diagnose PAH and exclude post capillary $\mathrm{PH}$, right heart catheterisation is required to assess hemodynamic impairment, conduct vasoreactivity test dan decide the operability of defect. ${ }^{5}$ Our study population indicated that most patients experience PAH (almost $80 \%$ ). Before performing right heart catheterisation, estimation of $\mathrm{PH}$ should be made by echocardiography. Those with high probability of $\mathrm{PH}$ in echocardiogram need to be confirmed with right heart catheterisation. ${ }^{5}$ While $77.6 \%$ of subjects had PH based on echocardiography result, the right heart catheterisation consistently detected similar proportion of subjects had PAH. It means, about $20 \%$ of subjects could be excellent candidates for ASD closure, because they did not develop PAH. In addition to mPAP level, the decision to close the defect can be reached by evaluating PARI value. Our data showed the wide range of PARI value, from 0.4 to 33.3 Wood Unit $/ \mathrm{m}^{2}{ }^{2}$ The current consensus suggests that patients with a PARI value $<4$ Wood Unit $/ \mathrm{m}^{2}$ can be operated, whereas those 
with PARI $>8$ Wood Unit $/ \mathrm{m}^{2}$ have inoperable disease. ${ }^{5}$ Derived from the consensus, $61.9 \%$ subjects can be closed and $23.9 \%$ subjects were contraindication to be closed. The rest, $11.2 \%$ subjects, were uncertain. However, some clinicians suggest to give aggresive drugs to reduce PARI value, in the hope that those with respond to the medication can benefit from closing the ASD.$^{10}$ While closing ASD mostly curative, some patients still develop some degree of PAH and therefore they still need PH lowering medication.

The higher proportion of young women in child-bearing age with secundum ASD suffering from significant $\mathrm{PH}$ raises question as to whether any mechanisms, other than hemodynamics and anatomy, present that make PH comes early. Larger data, such as registry, is necessary to answer the question through investigating the natural history or novel mechanism associating ASD with $\mathrm{PH}$. Furthermore, screening for congenital heart disease should be initiated as early as possible, because if it is detected during childhood the definitive treatment can be applied and the $\mathrm{PH}$ complication can be avoided. Unfortunately, currently no screening system available in Indonesia which mandate the simple cardiac examination such as auscultation to cardiac murmur or electrocardiography.

\section{CONCLUSION}

Most adult secundum ASD patients had developed PAH, mostly young women in productive ages, mainly visited hospital due to symptom related to $\mathrm{PH}$, the direction of blood flow mostly left to right side and mostly had reduced functional capacity.

\section{ACKNOWLEDGMENTS}

We were grateful to Monika Setiawan, MD and Aristida Cahyono, MD for the clinical data preparation. We were indebted to Ms. Sri Mardilah Wuryani, AMK for her excellent transthoracal echocardiogram acquisition.

\section{REFERENCES}

1. Beghetti M, Galiè N. Eisenmenger syndrome a clinical perspective in a new therapeutic era of pulmonary arterial hypertension. J Am Col Cardiol 2009; 53(9):733-40. http://dx.doi.org/ 1016/j.jacc.2008.11.025.

2. Reller MD. Prevalence of secundum atrial septal defect and associated findings, atrial septal defect. In: Rao S (ed.) Atrial Septal Defect. 31-36. Croatia: InTech, ISBN: 978953-51-0531-2

3. Webb G, Gatzoulis MA. Atrial septal defects in the adult: recent progress and overview. Circulation 2006; 114(15):1645-53.

4. Fuster V, Alexander RW, O'Rourke RA, et al. Hurst's the heart, ed. 11. New York: McGraw Hill. 2005; Vol 2.

5. Galiè N, Humbert M, Vachiery JL, Gibbs S, Lang I, Torbicki A, et al. 2015 ESC/ERS Guidelines for the diagnosis and treatment of pulmonary hypertension: the joint task force for the diagnosis and treatment of pulmonary hypertension of the European Society of Cardiology (ESC) and the European Respiratory Society (ERS): Endorsed by: Association for European Paediatric and Congenital Cardiology (AEPC), International Society for Heart and Lung Transplantation (ISHLT). Eur Heart J 2016; 37(1):67-119. http://dx.doi.org/ 10.1093/eurheartj/ehv317.

6. Engelfriet P, Meijboom F, Boersma E, Tijssen J, Mulder B. Repaired and open atrial septal defects type II in adulthood: an epidemiological study of a large European cohort. Int J Cardiol 2008; 126(3):379-85.

7. Toyono M. Pulmonary arterial hypertension in adults with atrial septal defect. J Cardiol Cases 2012; 6(1):e32-e33. http://dx.doi. org/10.1016/j.jccase.2012.04.005. 
8. Sommer RJ, Hijazi ZM, Rhodes JF Jr. Pathophysiology of congenital heart disease in the adult Part I: shunt lesions. Circulation 2008; 117(8):1090-9. http://dx.doi.org/ 10.1161/CIRCULATIONAHA.107.714402.

9. Huang JB, Liang J, Zhou LY. Eisenmenger syndrome: not always inoperable. Respir
Care 2012; 57(9):1488-95.http://dx.doi.org/ 10.4187/respcare.01418.

10. Nakanishi T. Pulmonary arterial hypertension associated with congenital heart disease. Personal perspectives. Int Heart J 2015; 56 Suppl:S1-3. http://dx.doi.org/10.1536/ihj.15064. 